\title{
BASIC DESIGN CRITERIA OF EXPELLING MA- CHINE FOR EXTRACTING WHEAT GERM OIL
}

\author{
El-Nono M.A. * ; A.M. Abdel-Gawad ${ }^{* *}$
}

\section{ABSTRACT}

An expelling machine for extracting wheat germ oil was designed and fabricated. The study included the investigation of the design criteria relating to hopper dimension and screw shaft parameters (outer diameter, pitch, thread depth, thread width, thread length, lead, lead angle, tapered angle, and number of turns on the screw shaft).

The expelling machine was tested and evaluated at five screw speeds (25, 35, 45, 55, and $65 \mathrm{rpm})$ and four levels of press head clearance $(0.5,1$, 1.5 , and $2 \mathrm{~mm}$ ) to determine the best machine capacity; percentage of oil recovery; percentage of residual oil; and specific energy consumption. The results showed that, the maximum machine capacity was $39 \mathrm{~kg} / \mathrm{h}$ of raw material at $2 \mathrm{~mm}$ outlet clearances, and $65 \mathrm{rpm}$ of screw speed. The best operating pressing conditions for the wheat germ oil recovery was $45.7 \%$ at the $25 \mathrm{rpm}$ of screw speed and $0.5 \mathrm{~mm}$ press head clearance, when the required specific energy was $0.0232 \mathrm{kWh} / \mathrm{kg}_{\text {feed }}$.

\section{Introduction}

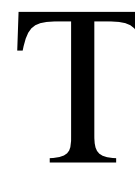

he shortage of both edible as well as non-edible oils and fats for industrial use has been continuing in Egypt for the past three decades. A local production of the vegetable oils is meager compared to their demand, so the shortage is met through imports from various sources. Undoubtedly, the agricultural sector should be endeavoring to minimize our dependence on imports but scientific and technological improvements also have a major role to play. In order to meet this shortage in oil, new vegetable oil resources are being sought, like wheat germ oil and rice bran oil.

Wheat germ, a nutritious by-product of flour milling industry constituting $2.5-3.0 \%$ of the grain can be separated in a fairly pure form by using a

\footnotetext{
* Agric. Eng. Dep., Fac. of Agric., Ain Shams Univ., Cairo, Egypt. ** Agric., Eng. Res. Inst. (AEnRI), Dokki- Giza, Egypt
} 
germ separator or by suitable adjustments in milling techniques. Wheat germ contains highly concentrated nutrients: 3 times as much protein, 7 times as much fat, 15 times as much sugar and 6 times as much minerals when compared to wheat flour. Additionally, wheat germ is the richest source of tocopherols (Dunford, 2005).

Statistical data on wheat germ production is not readily available. However it can be estimated that about 340 thousand tons of wheat germ could be obtained from wheat milling operations based on the fact that germ constitutes about $2 \%$ of the whole wheat grain and about 17 million metric tons of wheat in Egypt was consumed in 2009 (FAO, 2010). Even though it is a minor milling by-product, it is valuable owing to its nutritional and pharmaceutical properties (Bass, 1988). The well-known beneficial effects of wheat germ oils are basically due to their high content of vitamin E (Saito and Yamanchi, 1990) and unsaturated FA, mainly linoleic acid (18:2). Wheat germ oil has been shown to reduce plasma and liver cholesterol in animals and to delay aging (Horrobin, and Manku, 1983; Kahlon, 1989; Tong and Lawrence, 2001). Nevertheless, because of its unfavorable baking properties and susceptibility to oxidation, the germ is removed from the endosperm during milling and is mainly used for fodder and for oil production (Appelt, 1986).

Wheat germ oil is obtained either by solvent extraction, which recovers about $90 \%$ of the oil, or by mechanical pressing, which recovers about $50 \%$ (Singh and Rice, 1979). Khan and Hanna (1983) reported that to obtain greater extraction efficiency it becomes necessary to use powered devices and an oil expeller is the most common one. A whole range of expellers are available with capacities ranging from a few $\mathrm{kg} / \mathrm{h}$ up to tons/h, they all work on the same basic principle. The raw material, which may have been previously heated, it is fed by the worm shaft into a horizontal cylinder. A controllable pressure is built up in the cylinder by means of an adjustable choke at the cylinder exit. The internal pressure ruptures oil cells in the material and oil flows out through perforations in the cylinder cage.

Dhale and Modak, (2011) reported that his screw press method is less capital intensive, technically less extensive, compared with the solvent extraction method and less labor-intensive than the aqueous method. It is 
also continuous, unlike the hydraulic and the aqueous methods that are done batch wise. Also before solvent extraction method is applied, the oilseed is pre-pressed, hence these advantages of the screw press over the other methods make screw pressing popular and inevitable in future oilseed processing. To increase vegetable-oil production therefore, a good understanding of the working principles of the screw press is desirable.

Bredeson (1983) stated that the optimum condition in oil extraction is not only to obtain maximum oil yield, but also high quality products, i.e. oil and cake. For optimum performance, screw presses are designed for specified usage. In the laboratory, small quantities of oil are usually required for analysis; hence it is desirable that handle small quantities of oil-seed be provided. Although there are small-capacity screw presses in existence, the importation cost of such units is prohibitive; it is therefore desirable that the units be fabricated locally.

The purposes of this work were to determine the basic design criteria of expelling machine for extracting wheat germ oil, and evaluate the various factors affecting of machine performance.

\section{MATERIAL AND METHODS}

\subsection{Expelling machine description and operation:}

An expelling machine for extracting oil from wheat germ was designed and fabricated. As shown in Figs. (1) and (2), the machine components are: 1) Hopper (feeding inlet) to feed the materials into the feed end of the barrel, 2) Expellant screw shaft and expellant barrel, 3) Power unit (electric motor $4.1 \mathrm{~kW}$ and 1440rpm), 4) Power transition (pulleys, Vbelt and speed reducer (gear box)), and 5) Main frame where all the machine components were fixed. It is made of hollow square iron pipe $(40 \times 40 \times 40 \mathrm{~mm})$ and has the dimensions of $1100 \mathrm{~mm}$ length, $650 \mathrm{~mm}$ width, and $1150 \mathrm{~mm}$ height.

The screw with tapered inner shaft $(360 \mathrm{~mm}$ length, $60 \mathrm{~mm}$ outer diameter, $1.5^{\circ}$ taper angle) is designed, with constant pitch $(59 \mathrm{~mm})$, where the annular area is decreasing along the length of the screw shaft. It was made from austenitic steel (i.e. $0.3 \% \mathrm{C}, 18 \% \mathrm{Cr}$, and $8 \% \mathrm{Ni}$ ) and mounted between two bearings at ends. The barrel consists of 24 flat steel bars parallel to the worm shaft and the cross section of each bar is slightly trapezoidal. The whole set of the bars are functioned as lining bars which are fixed inside the surface of 
the cage, and acted as screen allowing the oil to pass but not the solid.

The main function of the present expelling machine is to compress wheat germ to produce oil and cake by expression procedures. The raw material is fed into the hopper of the expelling machine, and pass through the screw shaft, where the thread depth is reduced linearly allowing the wheat germ to be compressed between the inside walls of the barrel and the screw shaft up to the end of barrel where the cake is drained out. Oil is leaked out from the gaps between the bars of the barrel.

The expelling machine was tested for determining the best productivity and power consumption at five screw speeds $(25,35,45,55$, and $65 \mathrm{rpm})$ and at four levels of press head clearance $(0.5,1,1.5$, and $2 \mathrm{~mm})$.

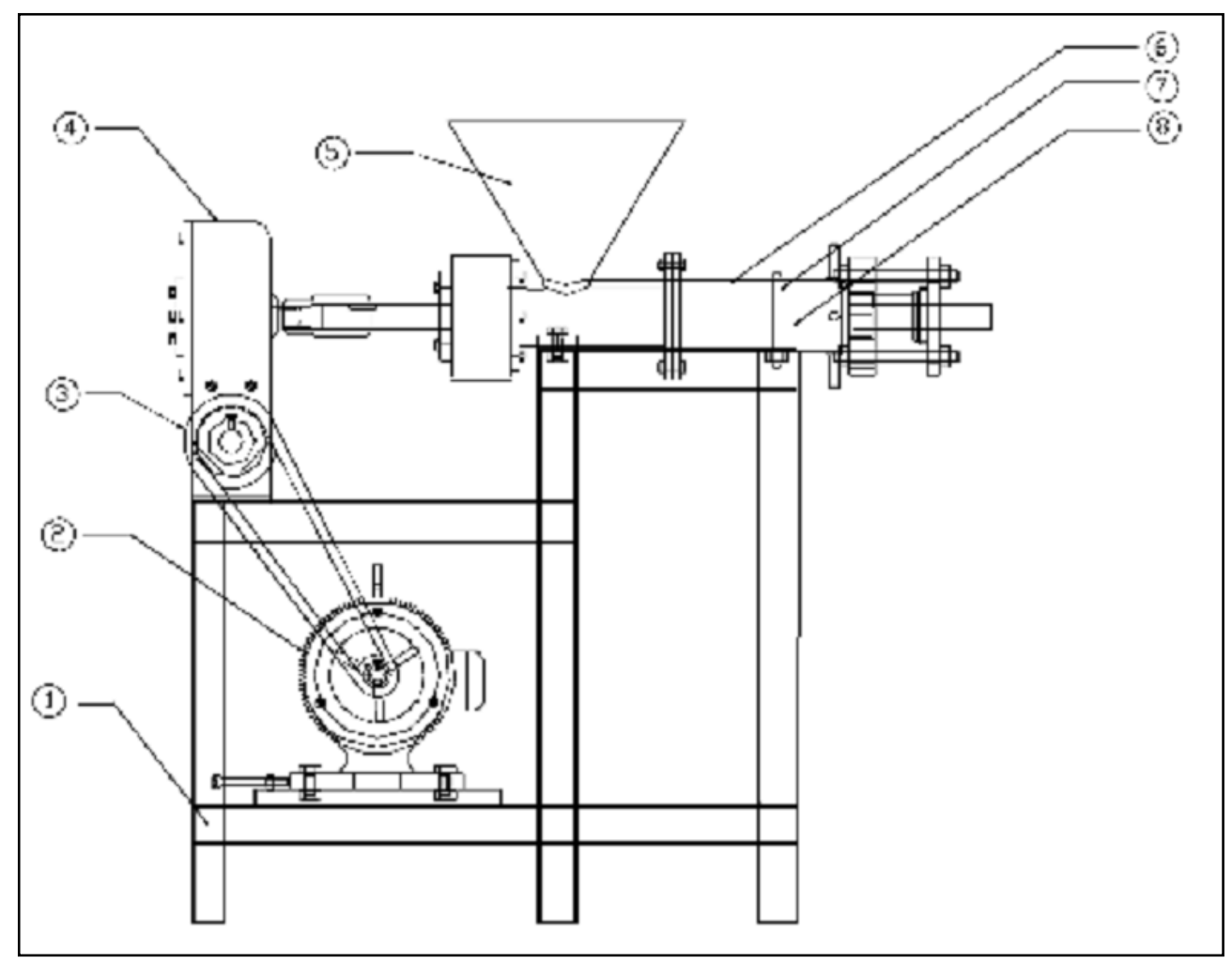

Fig.1. Schematic diagram of an expelling machine.

(1) Main frame (2) Electric motor (3) V-belt (4) Gear box

(5) Hopper (6) Barrel (7) Flange (8) Screw press (inside the barrel) 


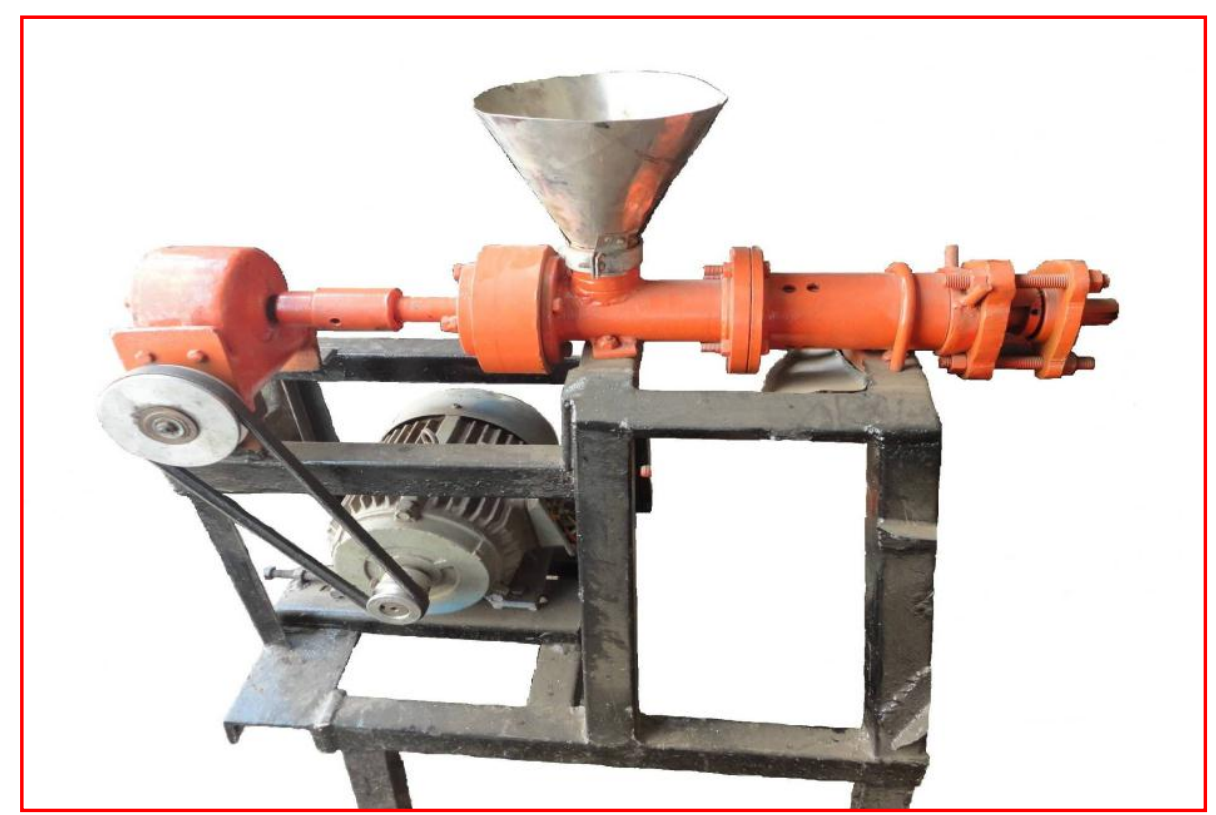

Fig. 2. Photograph of oil expelling machine.

\subsection{Design calculations:}

\subsubsection{Hopper}

Hopper shape was selected as frustum of a cone. It was fabricated from stainless steel sheet, the dimension and volume of the hopper was calculated based on the fact that the inclination angle of hopper $(\theta)$ must be greater than or equal the repose angle of wheat germ $(\varphi)$, i.e. $\theta \geq \varphi$.

The repose angle $(\varphi)$ was measured by using funnel methods (Chakraverty, 1987), and it was found equal to $35^{\circ}$, so the inclination angle of hopper $(\theta)$ was taken as $36^{\circ}$.

Theoretically, the hopper volume design must be adequate to the required wheat germ capacity (the volumetric flow rate). So, if the maximum required flow rate $(\dot{\mathrm{m}})$ is $30 \mathrm{~kg} / \mathrm{h}$, then

$$
Q_{T}=\frac{\dot{\mathrm{m}}}{\rho}
$$

Where:

$\mathrm{Q}_{\mathrm{T}}=$ Theoretical volumetric flow rate of wheat germ, $\mathrm{cm}^{3} / \mathrm{h}$. 
$\dot{\mathrm{m}}=$ The maximum required mass flow rate.

$\rho=$ Wheat germ bulk density. It was $0.5 \mathrm{~g} / \mathrm{cm}^{3}$, where the weight of $100 \mathrm{~cm}^{3}$ of uncompressed wheat germ was measured as 50 grams).

$$
\Rightarrow Q_{T}=\frac{30 \times 1000}{0.5}=6 \times 10^{4} \mathrm{~cm}^{3} / \mathrm{h}
$$

If the feeding efficiency $\eta_{f}$ (due to slippage of wheat germ inside the system) is taken as $90 \%$, then,

$$
Q_{a c t}=\frac{Q_{T}}{\eta_{f}}=\frac{6 \times 10^{4}}{0.9} 6.67 \times 10^{4}\left(\mathrm{~cm}^{3} / \mathrm{h}\right)
$$

Where, $Q_{\text {act }}$ is the actual volumetric flow rate of wheat germ, $\mathrm{cm}^{3} / \mathrm{h}$ If the required time interval $\left(\mathrm{t}_{\mathrm{int}}\right)$ between filling and re-filling up the hopper with raw material is $15 \mathrm{~min}$, and hopper volume efficiency $\left(\eta_{v}\right)$ is taken as $90 \%$, then,

$$
V_{H}=\frac{Q_{a c t} \times t_{\text {int }}}{\eta_{v}}=\frac{6.67 \times 10^{4} \times 15}{60 \times 0.9}=18.53 \times 10^{3} \mathrm{~cm}^{3}
$$

Where, $\mathrm{V}_{\mathrm{H}}$ is the hopper actual volume, $\mathrm{cm}^{3}$.

Since the lower hole diameter of the hopper $\left(\mathrm{d}_{\mathrm{H}}\right)$ should be greater than or equal the screw pitch $(\mathrm{P})$ in order to be large enough to prevent choking.

$$
\Rightarrow d_{H} \geq P \Rightarrow d_{H} \geq 59 m m \Rightarrow d_{H} \text { was taken as } 70 \mathrm{~mm} \text {. }
$$

The under hole diameter $\left(\mathrm{D}_{\mathrm{H}}\right)$, height $\left(\mathrm{h}_{\mathrm{h}}\right)$, and sidelong length $(\mathrm{x})$ of the hopper (frustum of cone shape) were calculated using the following equations (Harris and Stocker, 1998).

$$
h_{h}=\frac{12 \cdot V_{H}}{\pi \cdot\left(D_{h}^{2}+D_{h} d_{h}+d_{h}^{2}\right)}
$$

And,

$$
\tan \theta=\left(\frac{D_{h}-d_{h}}{2}\right) / h_{h}
$$

By solving equations 4 and $5, \mathrm{D}_{\mathrm{H}}=47.5 \mathrm{~cm}$, and $\mathrm{h}_{\mathrm{h}}=27.85 \mathrm{~cm}$,

Then, $\quad S_{h}=\sqrt{\left(\frac{D_{h}-d_{h}}{2}\right)^{2}+h_{h}^{2}}=34.43 \mathrm{~cm}$ 
PROCESS ENGINEERING

Where:

$\mathrm{D}_{\mathrm{h}}=$ Upper hole diameter of the hopper, $\mathrm{cm}$.

$\mathrm{h}_{\mathrm{h}}=$ Height of hopper, $\mathrm{cm}$.

$\mathrm{S}_{\mathrm{h}}=$ Sidelong length of the hopper, $\mathrm{cm}$.

Table 1: Showed the specification of suitable hopper dimensions of the expelling machine.

$\begin{aligned} V_{H} & =18.53 \times 10^{3} \mathrm{~cm}^{3} & \mathrm{~h}_{\mathrm{h}} & =27.85 \mathrm{~cm} \\ \mathrm{D}_{\mathrm{h}} & =47.5 \mathrm{~cm} & \mathrm{~S}_{\mathrm{h}} & =34.43 \mathrm{~cm} \\ \mathrm{~d}_{\mathrm{h}} & =7 \mathrm{~cm} & \theta & \theta=36^{\circ}\end{aligned}$

\subsubsection{Screw Shaft.}

The main view of the screw shaft is presented in Fig. (3). It is a tapered inner screw shaft where the pitch is constant $(59 \mathrm{~mm})$. The axial length of the screw shaft $\left(\mathrm{L}_{\mathrm{S}}\right)$ is measured as $360 \mathrm{~mm}$. It has 6 threads (number of turns of the screw shaft, $\mathrm{N})$, single thread, outer diameter $\left(\mathrm{d}_{\mathrm{S}}\right)$ of $60 \mathrm{~mm}$, and the tapered angle is selected to be $1.5^{\circ}(0.02618 \mathrm{rad})$, Oyinlola and Adekoya, (2004).

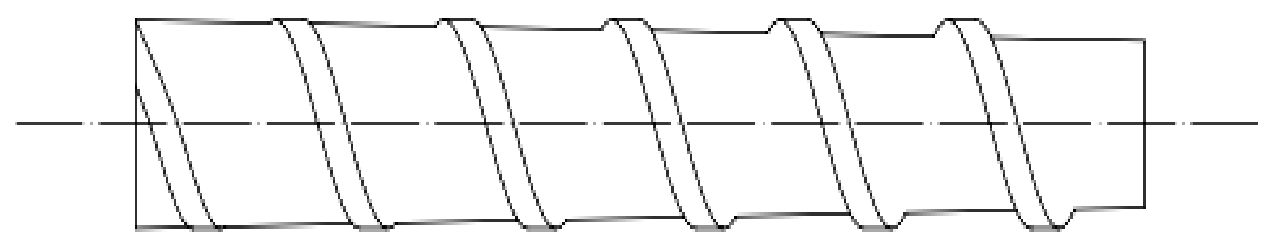

Fig. (3): Main view of screw shaft.

\subsubsection{Screw Parameters:}

\section{A) Screw pitch $(\mathrm{P})$.}

$$
\mathrm{P}=\frac{L_{S}}{N}=\frac{360}{6}=60 \mathrm{~mm}
$$

Where:

$$
\begin{aligned}
& L_{S}=\text { Axial length of the screw shaft, mm } \\
& \mathrm{N}=\text { Number of turns on the screw shaft. }
\end{aligned}
$$

It was taken as $59 \mathrm{~mm}$.

B) Lead $(l)$.

$$
l=\mathrm{P}=59 \mathrm{~mm}
$$

C) Lead angle $(\lambda)$. 
As shown in Fig (4), the lead angle was calculated using the following equation.

$$
\begin{array}{r}
\tan \lambda=\left(\mathrm{P} / \pi \mathrm{d}_{\mathrm{S}}\right)=\frac{59}{\pi \times 60}=0.313 \ldots \ldots . \\
\therefore \lambda=17.38^{\circ}=0.302 \mathrm{rad}
\end{array}
$$

Where:

$$
\begin{aligned}
& \lambda=\text { lead angle, rad; } \\
& \mathrm{d}_{\mathrm{S}}=\text { Outer diameter of screw shaft, } \mathrm{mm} .
\end{aligned}
$$

\section{D) Thread length $\left(\mathbf{L}_{t}\right)$.}

The thread length of the screw per one turn $\left(\mathrm{L}_{\mathrm{t}}\right)$ can be calculated using the following equation.

$$
\begin{array}{r}
L_{t}=2 \pi \sqrt{\left(\frac{d_{S}}{2}\right)^{2}+\mathrm{P}^{2}} \mathrm{P}^{2} \text { air, 2006).................. } \\
\therefore L_{t}=2 \pi \sqrt{\left(\frac{60}{2}\right)^{2}+59}=415.88 \mathrm{~mm}
\end{array}
$$

E) The total thread length (helix length) " $L_{T}$ ":

$$
\begin{array}{r}
L_{T}=L_{t} . N \ldots \ldots \ldots \ldots \ldots \ldots \ldots \ldots \ldots \ldots \ldots \\
L_{T}=415.9 \times 6=2495.4 m m
\end{array}
$$

\section{F) Thread depth (H)}

The linear decreasing in the thread depth $(\mathrm{H})$ along the total thread length is show in Fig.(5), and it is given by following equation (Sari, 2006)

$$
H(X)=\frac{H_{2}-H_{1}}{L_{S}} X+H_{1}
$$

Where $(\mathrm{X})$ is the measured distance along the helix length of the screw shaft from the inlet to the outlet. It is clear that the thread depth $\mathrm{H}_{2}$ is equal to zero at the last point of the screw (at the cake drainage), and it is equal to $\mathrm{H}_{1}$ (maximum thread depth) at the first point of the screw (at the feeding inlet).

Since the tapered angle may be written in terms of $\mathrm{H}_{1}$ and $\mathrm{H}_{2}$ as the following:

$$
\tan \alpha=\frac{H_{1}-H_{2}}{L_{S}} \Rightarrow \mathrm{H}_{1}=\mathrm{L}_{\mathrm{S}} \tan \alpha+\mathrm{H}_{2}
$$




$$
\therefore H_{1}=360 \tan 1.5^{\circ}+0=9.43 m m
$$

Where:

$\mathrm{H}_{1}=$ Height of the thread at the starting point of the turns of the screw shaft, $\mathrm{mm}$. (It was taken as $10 \mathrm{~mm}$ )

$\mathrm{H}_{2}=$ Height of the thread at the end point of the turns of the screw shaft, $\mathrm{mm}$.

$\mathrm{Z}=$ Variable distance measured along screw helix.

$\alpha=$ Taper angle of the screw shaft.

Now, the thread depth $\mathrm{H}(\mathrm{X})$ at any point $(\mathrm{X})$ along the total thread length could be determined by using equation (12).

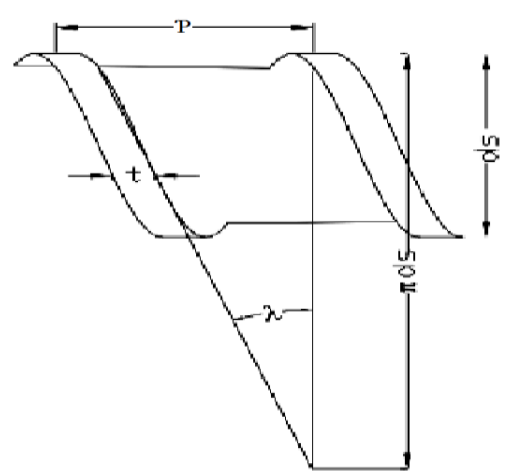

Fig. (4): Pitch and lead angle

\section{G) Thread width (t):}

Pressure distribution is assumed $t_{t}$ tse along the helix length of the screw in the third order a Lt ed in Fig. (6) (Sari, 2006). So, the maximum pressure $\left(\mathrm{P}_{2}\right)$ occurring at the cake drainage zone and applied on the threads area at the last turn of screw, which is determined as the following equations.

$$
T_{s}=\frac{60 . P}{2 \pi \cdot n}
$$




$$
T_{s}=\frac{60 \times 388}{2 \pi \times 65}=57 N m
$$

While,

$$
\begin{aligned}
& P_{2}=\frac{T_{S}}{V_{\text {displacement }}} \text { (Sabelli, 2004) } \\
& V_{\text {displacement }}=\frac{Q_{a c t}}{n} \\
& =\frac{6.67 \times 10^{4}}{65 \times 60 \times 10^{6}}=1.71 \times 10^{-5} \mathrm{~m}^{3} \\
& \therefore P_{2}=\frac{57}{1.71 \times 10^{-5}} \\
& =3.33 \times 10^{6} \mathrm{~N} / \mathrm{m}^{2} \cong 3.33 \mathrm{MP}
\end{aligned}
$$

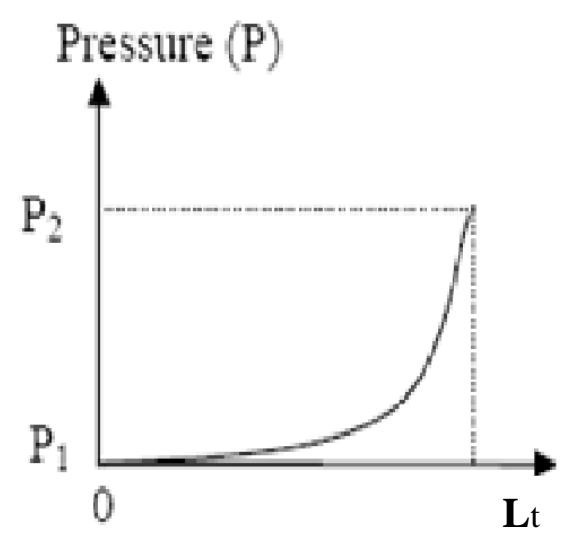

Fig. (6): Graph of assumed pressure distribution on the screw shaft from the inlet to outlet (Sari, 2006).

$$
\begin{aligned}
& F_{a}=\frac{T_{S}}{\left(d_{s} / 2\right)} \ldots \ldots \ldots \ldots \ldots \ldots . . . . . . \\
& \therefore F_{a}=\frac{57}{(0.06 / 2)}=1900 \mathrm{~N}
\end{aligned}
$$

But, the maximum unit force applied on the threads occurs at the last turn of screw.

$$
P_{2}=\frac{F_{a}}{t \times L_{t}}
$$

Then, $\quad t=\frac{F_{a}}{P_{2} \times L_{t}}$

$\therefore t=\frac{1900}{3.33 \times 10^{6} \times 0.4159} \cong 0.00137 \mathrm{~m}=1.37 \mathrm{~mm}$

By using factor of safety $=3 \Rightarrow t=4.11 \mathrm{~mm}$. Then, $(\mathrm{t})$ was taken as $10 \mathrm{~mm}$. Where:

$\mathrm{T}_{\mathrm{s}}=$ Torque of the screw shaft, $\mathrm{Nm}$.

$\mathrm{P}=$ The power requirement for oil extraction process, $\mathrm{W}$ (it was equal to $388 \mathrm{~W}$, at $65 \mathrm{rpm}$ screw speed and $0.5 \mathrm{~mm}$ outlet clearance). 
$\mathrm{V}_{\text {displacement }}=$ Volume displacement per one revaluation, $\mathrm{m}^{3}$ (it was equal to $1.71 \times 10^{-5} \mathrm{~m}^{3}$ at $65 \mathrm{rpm}$ screw speed when machine capacity measured as $30.6 \mathrm{~kg} / \mathrm{h}$ ).

$\mathrm{P}_{2}=$ the maximum presser applied on the threads, $\mathrm{MPa}$.

$\mathrm{F}_{\mathrm{a}}=$ the maximum unit force applied on the threads, $\mathrm{N}$.

$\mathrm{t}=$ Thread width, $\mathrm{mm}$.

\subsubsection{Stress analysis:}

The direction of moment, torque, reaction force, and pressure of the wheat germ are presented in Fig.(7). It is clear that the torque moment is collinear with the screw shaft axis, and the shaft that subjected to such a moment is said to be in torsion, where the shear stress is given by the following equation.

$$
\tau_{y z}=K_{f} \frac{T_{s} . r}{J} \quad \text { (Spotts, 1971). }
$$

Where the moment due to the weight of the shaft $\left(\mathrm{M}_{\mathrm{s})}\right.$ is negligible compared to the torque moment $\left(\mathrm{T}_{\mathrm{S}}\right)$.

Since the maximum shear stress is acted at the maximum critical crosssection of the screw shaft, where the shaft diameter is minimum $\left(\mathrm{d}_{1}\right)$, as shown in Fig.(7), then equation (18) could be written as:

$$
\tau_{\max }=\tau_{y z}=K_{f} \frac{T_{s} \cdot\left(d_{1} / 2\right)}{\frac{\pi}{32} \cdot d_{1}^{4}}
$$

Where, $\quad \tau_{x z}=\tau_{z x}=0$
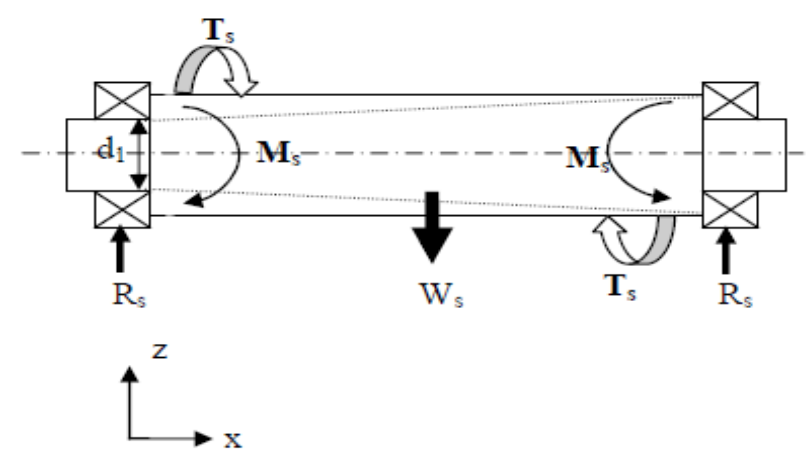
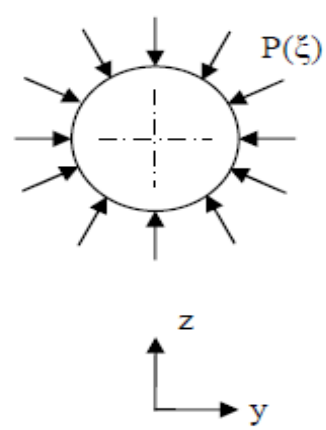

Fig. (7): Free body diagram of the screw shaft. (Sari, 2006) 
Where:

$\mathrm{r}=$ The radius to the inner diameter of screw shaft, $\mathrm{mm}\left(\mathrm{d}_{1} / 2\right)$;

$\mathrm{d}_{1}$ : Smallest diameter of the screw shaft, $\mathrm{mm}$.

$\mathrm{J}=$ Polar moment of inertia of circular cross section, $\mathrm{mm}^{4}\left(\pi \mathrm{d}_{1}{ }^{4} / 32\right)$;

$\mathrm{K}_{\mathrm{f}}=$ Stress concentration factor (equal 3, According to Unified and American Thread Design)

$\mathrm{M}_{\mathrm{s}}$ : Moment at the most critical cross section arising from the weight of the screw shaft.

$\mathrm{R}_{\mathrm{s}}$ : Reaction forces acting on the screw shaft at two ends.

$\mathrm{W}_{\mathrm{s}}$ : Weight of the screw shaft, $\mathrm{N}$.

$\tau_{\max }=$ Maximum shear stress, MPa.

$$
\tau_{\max }=3 \times \frac{57 \times(0.04 / 2)}{\frac{\pi}{32} .(0.04)^{4}}=13607747.6 \mathrm{~N} / \mathrm{m}^{2}=13.6 \mathrm{MPa}
$$

Using factor of safety $\left(F_{S}\right)=2$, then the $\tau_{\max }=27.2 \mathrm{MPa}$ which is less than the maximum yield strength of the screw shaft material that was selected as austenitic steel which has yield strength $\left(\delta_{s}\right)$ of $260 \mathrm{MP}_{\mathrm{a}}$ (the maximum shear stress for material $\left(\tau_{\max }=\delta_{s} / \mathrm{F}_{S}=260 / 2=130 \mathrm{MPa}\right)$

Table (2) Specification of major component of the model screw press.

\begin{tabular}{llllll}
\hline $\mathrm{L}_{\mathrm{S}}=360 \mathrm{~mm}$ & $\mathrm{~L}_{\mathrm{t}}=415.9 \mathrm{~mm}$ & $\alpha$ & $=1.5^{\circ}(0.026 \mathrm{rad})$ \\
$\mathrm{d}_{\mathrm{S}}=60 \mathrm{~mm}$ & $\mathrm{~L}_{\mathrm{T}}=2495 \mathrm{~mm}$ & $\delta_{s}$ & $=260 \mathrm{MPa}$ \\
$\mathrm{d}_{1}=40 \mathrm{~mm}$ & $\mathrm{~N}$ & $=6$ & $\tau_{\max }$ & $=27.2 \mathrm{MPa}$ \\
$\mathrm{H}_{1}=10 \mathrm{~mm}$ & $\mathrm{P}$ & $=59 \mathrm{~mm}$ & $\mathrm{P}_{2}$ & $=3.33 \mathrm{MPa}$ \\
$\mathrm{t}$ & $=10 \mathrm{~mm}$ & $\mathrm{~T}_{\mathrm{S}}$ & $=57 \mathrm{Nm}$ & $\lambda$ & $=17.3^{\circ}(0.3 \mathrm{rad})$
\end{tabular}

\section{Performance Evaluation:}

The expelling machine was evaluated at five screw speeds $(25,35,45,55$, and $65 \mathrm{rpm})$, and four levels of press head clearance $(0.5,1,1.5$ and $2 \mathrm{~mm})$, at constant moisture content of fresh wheat germ (13.2\%). By using the following indicators:

3.1. Machine capacity $(\mathrm{kg} / \mathrm{h})$ was calculated by the following equation:

$$
\mathrm{P}_{\mathrm{m}}=\mathrm{W} / \mathrm{t}_{0}
$$

Where:

$\mathrm{P}_{\mathrm{m}}=$ Machine capacity, $\mathrm{kg} / \mathrm{h}$. 
$\mathrm{W}=$ Machine feeding, $\mathrm{kg}$.

$\mathrm{t}_{0}=$ Machine operating time, $\mathrm{h}$.

3.2. Percentage of oil recovery (OR) was defined as the ratio of oil weight in the product oil to original weight in the wheat germ that was pressed (Beerens, 2007). It was computed as following:

$$
O R=\left(1-\frac{W_{C} O_{C}}{W_{m} O_{m}}\right) \times 100 \%
$$

Where:

$$
\begin{aligned}
& \mathrm{W}_{\mathrm{C}}=\text { Mass of cake, } \mathrm{g}, \\
& \mathrm{O}_{\mathrm{C}}=\text { Oil content of cake, } \mathrm{g} ; \\
& \mathrm{W}_{\mathrm{m}}=\text { Mass of sample, } \mathrm{g}, \text { and } \\
& \mathrm{O}_{\mathrm{m}}=\text { Initial oil content of sample, } \mathrm{g} .
\end{aligned}
$$

3.3. Percentage of remaining oil was determined by using Soxhlet apparatus technique and redistilled n-hexane according to the method of (AOCS, 1996). Percentage of residual oil was calculated using the following equation:

Percentage of remaining oil $=\left(\mathrm{O}_{\mathrm{C}} / \mathrm{O}_{\mathrm{m}}\right) \times 100$ Where:

$$
\begin{aligned}
& \mathrm{O}_{\mathrm{C}}=\text { Oil content of cake, } \mathrm{g} \text {; and } \\
& \mathrm{O}_{\mathrm{m}}=\text { Initial oil content of sample, } \mathrm{g} .
\end{aligned}
$$

\subsection{Specific Energy Consumption (SEC):}

The power requirement for expelling machine was calculated by using the clamp meter to measure the line current strength and the potential difference value. The total electric power requirement under expeller working load was calculated according to (Chancellor, 1981) and (Ibrahim, 1982) by the following equation:

$$
\mathrm{P}=(\mathrm{I} \times \mathrm{V} \times \cos \theta) / 1000
$$

Where: $\mathrm{P}=$ The power requirement for extracting oil, $\mathrm{kW}$.

$\mathrm{I}=$ Line current strength, Amperes.

$\mathrm{V}=$ Potential difference, Voltage.

$\operatorname{Cos} \theta=$ Power factor, equal to 0.85 .

The specific energy consumption of expelling machine SEC $(\mathrm{kWh} / \mathrm{kg})$ was calculated by the following equation.

$$
\mathrm{SEC}=\left(\mathrm{P} / \mathrm{P}_{\mathrm{m}}\right)
$$




\section{RESULT AND DISCUSSION}

\subsection{Machine capacity $(\mathrm{kg} / \mathrm{h})$ :}

As shown in Fig. (8), the machine capacity increased with the increase of screw speed, and decreased with the decrease of the outlet clearance. It was increased by $43.1 \%$ by increasing screw speed from 25 to $65 \mathrm{rpm}$ at $0.5 \mathrm{~mm}$ of outlet clearance. Also, it was decreased by $30.9 \%$ by decreasing outlet clearance from 2 to $0.5 \mathrm{~mm}$ at $25 \mathrm{rpm}$ of screw speed. The maximum machine capacity of $39 \mathrm{~kg} / \mathrm{h}$ was obtained with $2 \mathrm{~mm}$ outlet clearance and 65rpm screw speed. Meanwhile, the minimum machine capacity of $17.4 \mathrm{~kg} / \mathrm{h}$ was obtained at $0.5 \mathrm{~mm}$ outlet clearance and $25 \mathrm{rpm}$ screw speed.

\subsection{The percentage of oil recovery:}

Fig. (9) Shows that, the percentage of oil recovery increased with the decrease of the outlet clearance, while it was decreased with the increase of screw speed. The maximum oil recovery was obtained at $0.5 \mathrm{~mm}$ outlet clearance and $25 \mathrm{rpm}$ of screw speed when a total of $45.7 \%$ of the available oil in the sample was recovered. At $0.5 \mathrm{~mm}$ outlet clearance the oil recovery decreased from 45.7 to $37.12 \%$ with increasing screw speed from 25 to $65 \mathrm{rpm}$, while at $1 \mathrm{~mm}$ outlet clearance, it was decreased from 43.6 to $33.8 \%$ and from 41.7 to $31.9 \%$ at $1.5 \mathrm{~mm}$ outlet clearance. Meanwhile at $2 \mathrm{~mm}$ outlet clearance it was decreased from 39.9 to $29.6 \%$, with increasing screw speed from 25 to $65 \mathrm{rpm}$ respectively.

\subsection{The percentage of residual oil:}

Fig. (10) Indicates that, the percentage of residual oil decreased with the decrease of the outlet clearance and the decrease of screw speed. It was decreased by $9.7 \%$ by decreasing outlet clearance from 2 to $0.5 \mathrm{~mm} \%$ at $25 \mathrm{rpm}$ of screw speed. Also, it was decreased by $13.6 \%$ by decreasing screw speed from 25 to $65 \mathrm{rpm}$ at $0.5 \mathrm{~mm}$ of outlet clearance. The minimum the percentage of residual oil $(54.3 \%)$ was obtained at $0.5 \mathrm{~mm}$ outlet clearance and $25 \mathrm{rpm}$ of screw speed. Meanwhile, the maximum the percentage of residual oil (70.4\%) was obtained at $2 \mathrm{~mm}$ outlet clearance and $65 \mathrm{rpm}$ of screw speed.

\subsection{Specific Energy Consumption (SEC) $(\mathrm{kWh} / \mathrm{kg}$ feed $)$ :}

Results illustrated in Fig. (11), show that SEC increased with the decrease of the outlet clearance, while it had a little increase with increasing of the screw speed from 25 to $65 \mathrm{rpm}$ at the same outlet clearance. At 0.5 outlet clearance the SEC increased from 0.0232 to $0.0243 \mathrm{kWh} / \mathrm{kg}_{\text {feed }}$ when the screw speed increased from 25 to $65 \mathrm{rpm}$, respectively. 


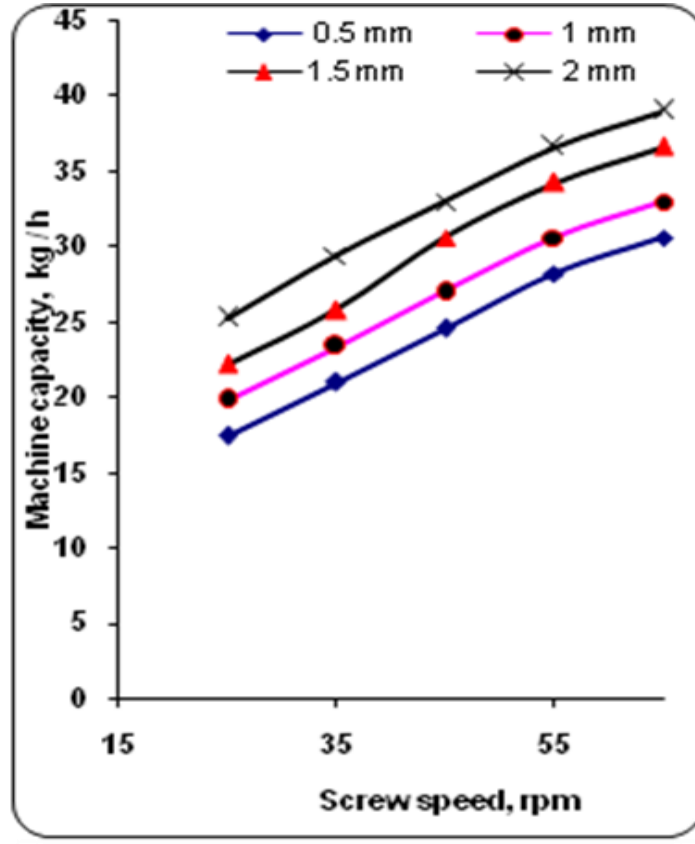

Fig. 8: Effect of screw speed and outlet clearance on machine capacity $\mathrm{Kg} / \mathrm{h}$.

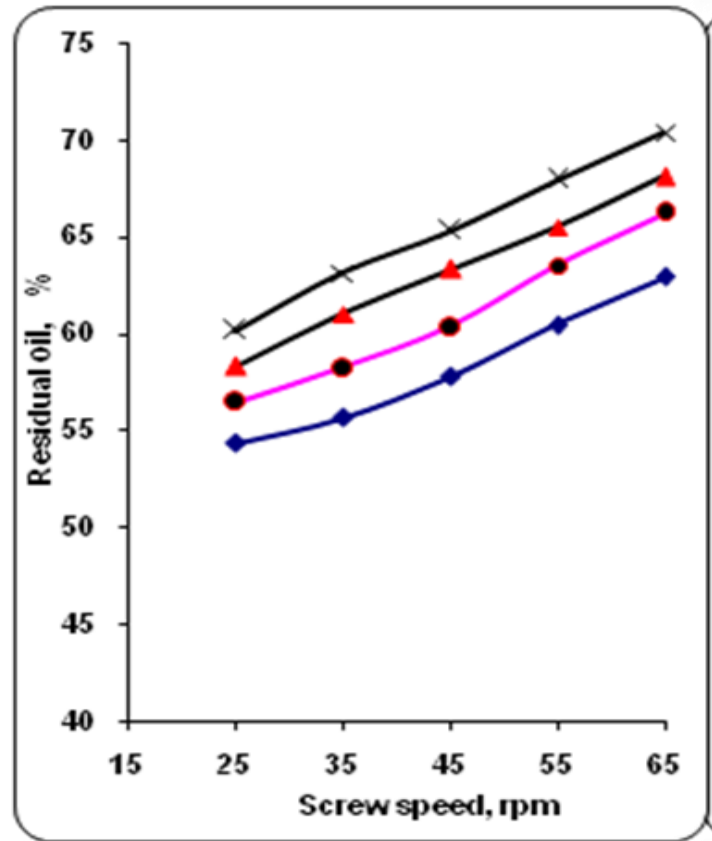

Fig. 10: Effect of screw speed and outlet clearance on residual oil, $\%$, in wheat germ cake.

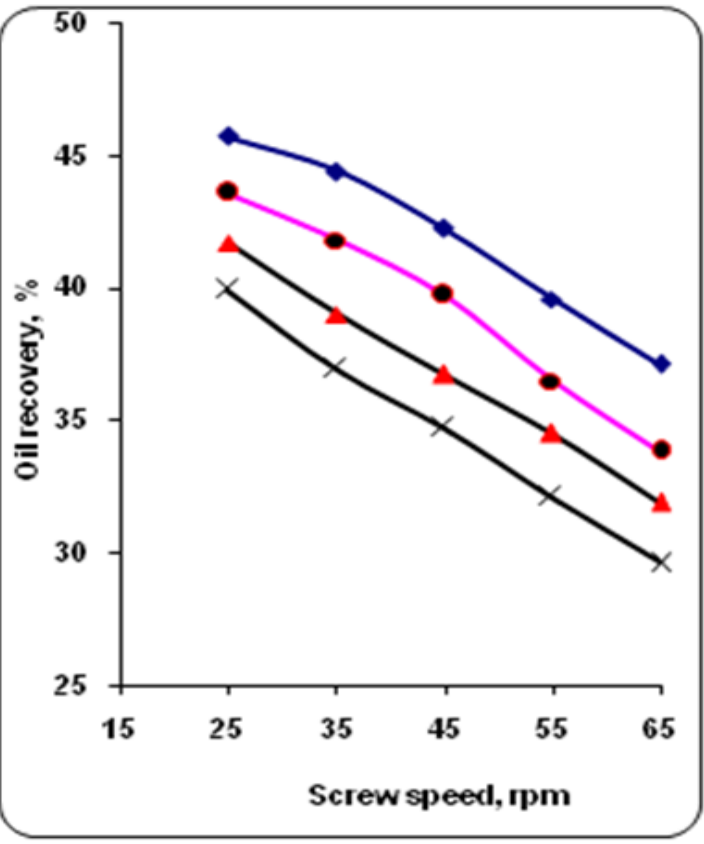

Fig. 9: Effect of screw speed and outlet clearance on oil recovery, $\%$.

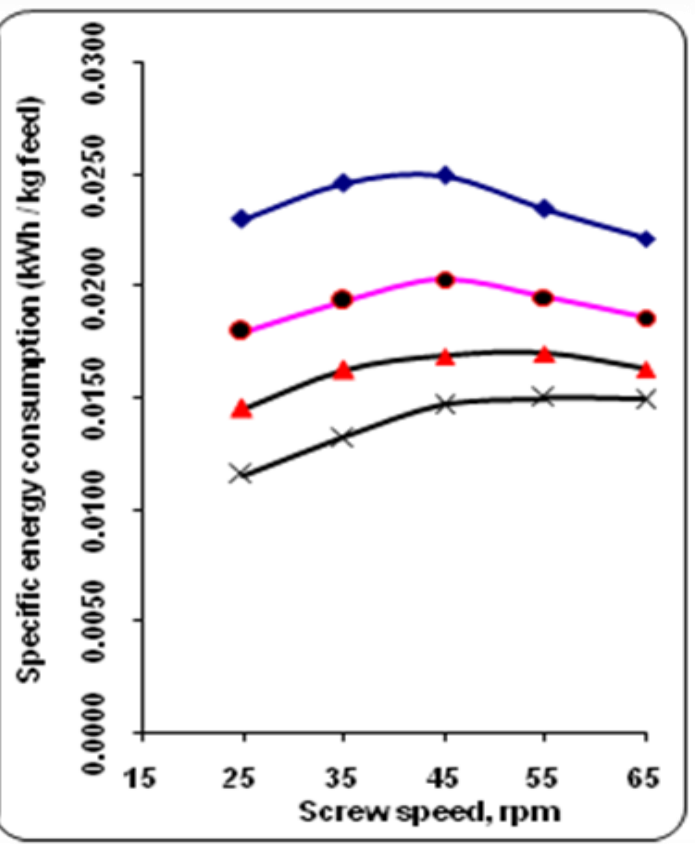

Fig.11: Effect of screw speed and outlet clearance on specific energy consumption ( $\mathrm{kWh} / \mathrm{kg}_{\text {feed }}$ ) 


\section{CONCLUSION}

The component design of a wheat germ oil expelling machine was successfully carried out, and the machine is fabricated.

The machine capacity, percentage of oil recovery, percentage of residual oil, and specific energy consumption are directly affected by screw speeds and press head clearance, the results of the evaluation show that the machine satisfies its objectives. The best operating pressing conditions for the wheat germ oil recovery was $45.7 \%$ at $25 \mathrm{rpm}$ screw speed and $0.5 \mathrm{~mm}$ press head clearance, when the specific energy requirement was $0.023 \mathrm{kWh} / \mathrm{kg}_{\text {feed }}$.

\section{REFERNCES}

Appelt, G. (1986). Nutritional value and stability of extruded wheat germ product, Getreide Mehl Brot 40:176-180.

AOCS, (1996). The Official and Tentative Methods of the American Oil Chemist's Society, 3rd Ed. American Oil Chemist's Society, 508 South Sixth Street, Champaign, Illinois.

Bass, E.J. (1988). Wheat flour milling, in Wheat: Chemistry and Technology, edited by Y. Pomeranz, American Association of Cereal Chemists, St. Paul, , Vol. 2, pp. 1-56.

Beerens, P. (2007). Screw-pressing of Jatropha seeds for fuelling purposes in less developed countries. M.Sc. Thesis, Department of Sustainable Energy Technology, Eindhoven University of Technology, Eindhoven, p. 87.

Bredeson, D. K. (1983). Mechanical extraction. Journal of American Oil Chemists Society, 60(2), 211-213.

Chancellor, W. J. (1981). Substituting information for energy in agricultural. Trans. ASAE, Paper No. 0001- 2351.

Chakraverty, A. (1987). Post harvest technology of cereals, pulses and oil seeds (Revised Edition). Oxford and IBH Publishing Co. PVT LTD. New Delhi. Bombay, Calcutta.

Dhale A.D. and J.P. Modak (2011). Design and development of oil seed presser by using energy source as human powered flywheel motor. International Journal of Agriculture and Food Science Technology. Vol. 2, No. 1, pp. 63-72. 
Dunford, N. T. (2005). Germ oils from different sources. In: Bailey's Industrial Oil and Fat Products, $6^{\text {th }}$ Ed. Editor: F. Shahidi. John Wiley and Sons, N.J. Vol. 3, "Edible Oil and Fat Products: Specialty Oils and Oil Products", Ch. 8, pp. 195-231.

FAO, (2010). Production year book, for 2009. Food and Agriculture Organization of the United National. Rom. http://www.fao.org/corp/statistics/en/

Ibrahim, M. K. E. (1982). Wet Milling Wheat Grain. Master thesis of science. Fac. of Agric. Mansoura Univ., 64-65.

Harris, J. W. and H. Stocker (1998). "Frustum of a Right Circular Cone." in Handbook of Mathematics and Computational Science. New York: Springer-Verlag, p. 105.

Horrobin, D. and M. Manku (1983). How do polyunsaturated fatty acids lower plasma cholesterol levels? Lipids 18:558-562.

Khan, L. M. and M. A. Hanna (1983). Expression of oil from oil seeds. A review. J. Agric. Eng. Res., 28(6), 495-503.

Kahlon, T.S. (1989). Nutritional implications and uses of wheat and oat kernel oil, Cereal Foods World 34:872-875.

Oyinlola A. and L.O. Adekoya (2004). Development of a laboratory model screw press for peanut oil expression. J. Food Eng., 64: 221227.

Sabelli A. M. (2004). Design of a Press for Oil Extraction from Moringa Seeds for Haiti. Bachelor thesis of science, Department of Mechanical Engineering, Massachusetts Institute of Technology. Haiti.

Saito, M., and Y. Yamanchi (1990). Isolation of tocopherols from wheat germ oil by recycles semi preparative supercritical fluid chromatography, J. Chromatogr. Sci. 505:257-271.

Sari, P. (2006). Preliminary Design and Construction of a Prototype Canola Seed Oil Extraction Machine. Master thesis of science. Department of Mechanical Engineering, Middle East Technical Univ., Ankara, Turkey.

Singh, L. and W.K. Rice (1979). Method for producing wheat germ lipid product, U.S. Patent 4,298,622. 
Spotts, M. F. (1971). Design of machine elements (4th ed.). Englewood Cliffs, NJ: Prentice Hall Inc.

Tong, W. and A.J. Lawrence (2001). Refining high-free fatty acid wheat germ oil. J. Am Oil Chem. Soc. 78:71-76.

\section{الملخص العربي}

\section{معايير التصميم الأساسية لآلة فصل لآستخلاص زيت جنين القمح}

$$
\text { د. محمود أحمد النونو*، م. عبدالجواد محمد سعد** }
$$

تعاني مصر من قصورا كبير ا في إنتاج الزيوت النباتية حيث وصلت الفجوة الغذائية من

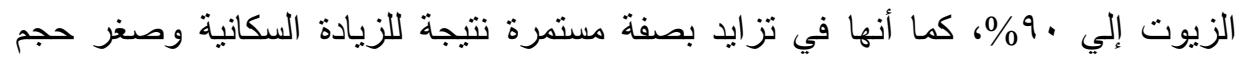

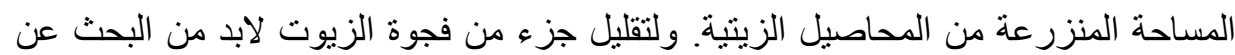

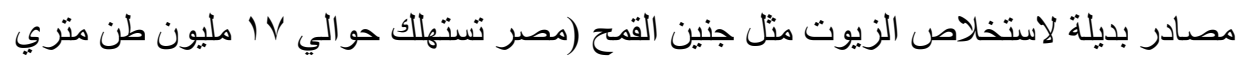

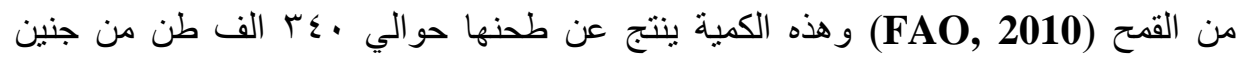

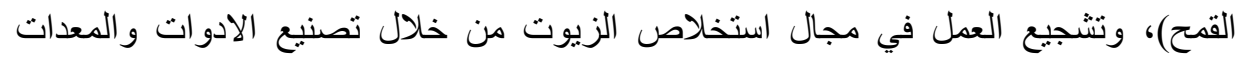

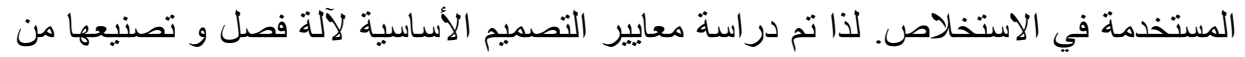

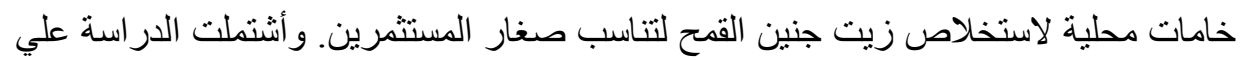

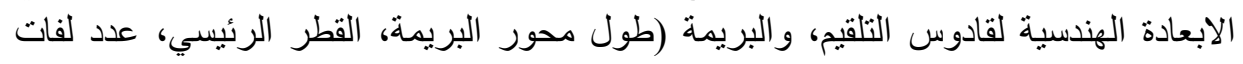

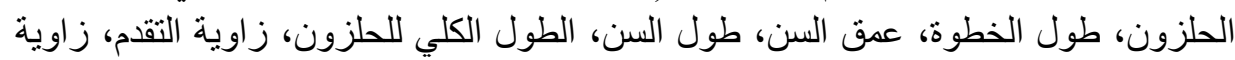

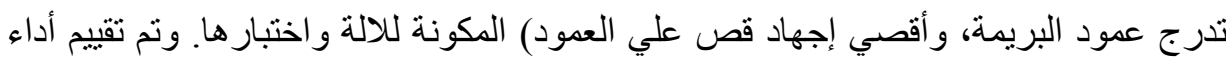

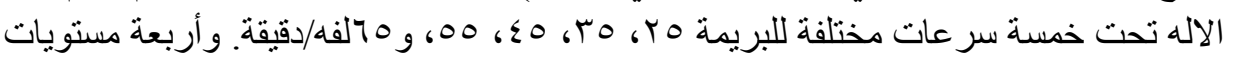

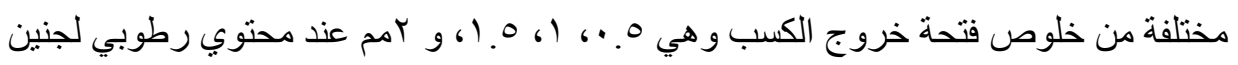
القمح ب.r\%

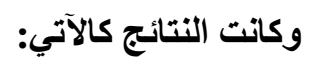

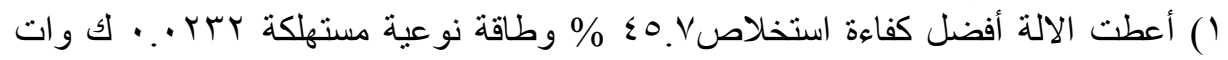

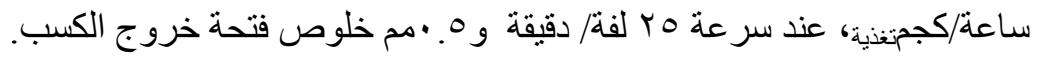

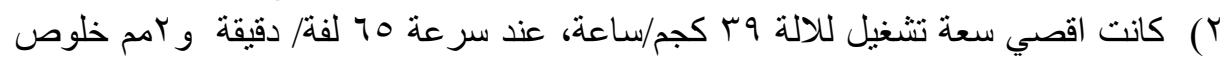

$$
\text { فتحة خروج الكسب. }
$$

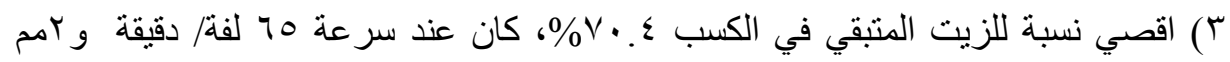

$$
\text { خلوص فتحة خروج الكسب. }
$$

* قسم الهندسة الزراعية ـ كلية الزراعة - جامعة عين شمس - القاهرة.

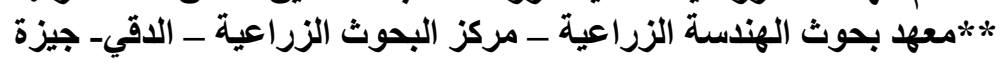

